SHORT COMMUNICATION

\title{
Infestation of thornbird nests (Passeriformes: Furnariidae) by Psammolestes tertius (Hemiptera: Reduviidae) across Brazilian Cerrado and Caatinga ecoregions
}

\author{
Rodrigo Gurgel-Gonçalves ${ }^{1,2} \&$ César Augusto Cuba Cuba ${ }^{1}$
}

${ }^{1}$ Laboratório de Parasitologia Médica e Biologia de Vetores, Faculdade de Medicina, Área de Patologia, Universidade de Brasília. Asa Norte, 70910-900 Brasília, DF, Brazil.

2 Corresponding author. E mail: rgurgel@unb.br

\begin{abstract}
Psammolestes tertius Lent \& Jurberg, 1965 is a sylvatic triatomine bug species that occurs in thornbird nests in Brazil. We studied infestation of 527 nests of Phacellodomus rufifrons Wied, 1821 and Phacellodomus ruber Vieillot, 1817 by $P$. tertius in eight Brazilian states across the Cerrado and Caatinga ecoregions. Psammolestes tertius occurred in $44 \%$ of the nests, mainly in those of $P$. ruber. Overall, 3,261 specimens (52\% nymphs) were captured, with an average of 14 bugs per infested nest (range 1-75). While $P$. tertius occurrence and age structure (percentage of nymphs) were similar in Cerrado and Caatinga nests, infestation intensity (bugs/infested nest) was higher in the Cerrado. Last-stage nymphs and adults were predominant in $P$. tertius populations from both $P$. ruber and $P$. rufifrons nests. The results indicate that Phacellodomus nests are favourable habitats for $P$. tertius in the open/dry ecoregions of Brazil. The percentage of adult $P$. tertius specimens (48\%) was higher than that observed in other triatomine species (usually less than $5 \%$ under either experimental or natural conditions), suggesting that adult bugs tend to remain in thornbird nests. The stable blood supply provided by resident/breeding birds would favor steady $P$. tertius infestation of thornbird nests across Brazilian Cerrado and Caatinga ecoregions.
\end{abstract}

KEY WORDS. Triatominae; Rhodniini; Synallaxinae; Brazil.

Psammolestes tertius Lent \& Jurberg, 1965 is a sylvatic triatomine species widely distributed in Brazil (GURGEL-GONÇALVES $\&$ SILVA 2009), where it is found in association with various bird species (Di Iorio \& Turienzo 2009). Furnariids such as Phacellodomus rufifrons Wied, 1821 (Lent \& Jurberg 1965, Sherlock \& Guitton 1974, Silva \& Lustosa 1993), Phacellodomus ruber Vieillot, 1817 (Gurgel-Gonçalves et al. 2004, GurgelGonÇalves \& Cuba 2007), and Anumbius annumbi Vieillot, 1817 (Barretto \& Carvalheiro 1968, Turienzo \& Di Iorio 2008) are the main hosts of this blood-sucking bug. Although $P$. tertius has been experimentally infected with Trypanosoma cruzi Chagas, 1909, the bird-feeding habit and strictly sylvatic habitats of this species suggest that it is not involved in the transmission of this protozoan parasite (SILVA \& LusTosa 1993).

Several aspects of $P$. tertius biology and ecology, including distribution, have already been described (see references above). However, the patterns of furnariid nest infestation by this triatomine species remain poorly understood. The aim of this study was to analyze infestation of thornbird nests (P. ruber and $P$. rufifrons) by $P$. tertius populations across the Brazilian Cerrado and Caatinga ecoregions.
The Cerrado is characterized by savanna vegetation (ranging from open grasslands to closed gallery forests) and a marked seasonality with a dry season between May and September. The Caatinga is the largest dry forest ecoregion in South America; vegetation ranges from low shrubby Caatinga, associated with shallow sandy soils, to tall Caatinga forest associated with eutrophic soils. Climate is hot and dry, with low annual precipitation values and 6 to 11 dry months (WWF 2001). Further ecological characteristics of the areas where $P$. tertius occurs were detailed elsewhere (GURGeL-Gonçalves \& SiLva 2009).

Nests of $P$. ruber were collected in Mauritia flexuosa L. palm tree crowns according to GurgeL-Gonçalves et al. (2003). Nests of $P$. rufifrons were sampled after cutting branches of the support trees (SiLva \& Lustosa 1993). The nests were inspected on a white cloth to assist in the detection of bugs. Between July 2005 and September 2010, we sampled 39 nests (36 of $P$. ruber and 3 of $P$. rufifrons rufifrons) in 16 Cerrado localities of 6 Brazilian states (Goiás, Mato Grosso, Bahia, Minas Gerais, São Paulo, and Maranhão) and the Federal District. Bugs were separated by sex (adults) and stage (nymphs) and counted. Additionally, we reviewed the literature and retrieved bug infestation 
data for 318 P. rufifrons rufifrons nests from 20 Cerrado localities (states of Minas Gerais, São Paulo and Goiás) (Barretto \& Carvalheiro 1968, Mello 1981, 1982, Silva \& Lustosa 1993) and 170 P. rufifrons specularis nests from 27 Caatinga localities (state of Pernambuco) (Lucena \& Lucena 1965).

Psammolestes tertius occurred in $44 \%$ of the thornbird nests surveyed, mainly in those of $P$. ruber (Tab. I). Overall, 3,261 specimens ( $52 \%$ nymphs) were collected, with an average of 14 bugs per infested nest. Both $P$. tertius occurrence and age structure (measured as the percentage of nymphs) were similar in nests sampled in either the Cerrado or Caatinga ecoregions. Infestation intensity (measured as the average number of bugs per infested nest) was nonetheless higher in Cerrado thornbird nests (Tab. I). The number of adult and immature bugs was also similar in the nests of $P$. ruber and $P$. rufifrons; in both cases, last-stage nymphs and adults predominated (Fig. $1)$.

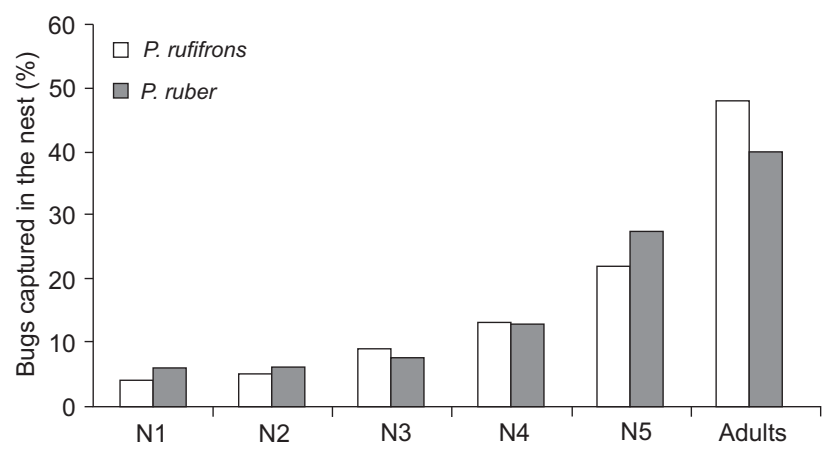

Figure 1. Percentage of Psammolestes tertius specimens captured in the nests of Phacellodomus rufifrons and P. ruber, according to their development stages. (N) Nymphs.

These results indicate that, as previously suggested (LENT \& Jurberg 1965, Sherlock \& Guitton 1974, SiLVA \& Lustosa 1993, Gurgel-Gonçalves et al. 2004, Gurgel-Gonçalves \& Cuba 2007) Phacellodomus nests are favourable habitats for $P$. tertius populations in the open/dry ecoregions of Brazil. As noted by AвADFranch et al. (2009), both Psammolestes spp. and Synallaxinae furnariids are trans-Amazonian vicariants; these authors proposed that the Psammolestes arose from a single lineage within the genus Rhodnius in association with ancestral synallaxines that built large vegetative nests in open, semi-arid woodland and savannas. Some biological and behavioral features of these thornbirds may result in suitable conditions for $P$. tertius colonies; thus, thornbirds: a) build large nests, which can reach 2 $\mathrm{m}$ long and a width of about $40 \mathrm{~cm}$; b) are territorial, with up to several individuals using their nests throughout the year to sleep and breed, with the offspring remaining in their in parental territory for several months; and c) reuse the same nests over several breeding seasons. Additionally, thornbird nests are often used by several other birds (inquilines) (SкUтсн 1969, Carrara \& Rodrigues 2001). The lower abundance of $P$. tertius in the nests of $P$. rufifrons specularis may be related to the semiarid conditions of the Caatinga ecoregion.

Regarding $P$. tertius population age structure, $48 \%$ of all specimens collected in thornbird nests were adults. Considering only our field data from nests sampled in the rainy season, the percentage of adults was as high as $51 \%$. According to BAR et al. (1999), Psammolestes coreodes Bergroth, 1911 populations that occur in bird nests in Argentina are composed mainly of adult specimens (63\% of all bugs caught). Psammolestes tertius and $P$. coreodes populations therefore differ sharply from other triatomine bug populations, in which immature stages are predominant and adults generally account for less than 5\% under either experimental (Rabinovich 1972, Cabello et al. 1987, OsCHerov et al. 1996, 2005) or natural conditions (BAR et al. 1992, 1993, Diotaiuti et al. 1993).

The high proportion of adults in $P$. tertius populations from thornbird nests could be explained by a combination of high longevity and low dispersal of adult bugs from the nests. As described by SiLVA \& Lustosa (1993), the average longevity of $P$. tertius nymphs (fifth stage) and adults under experimental starvation conditions is approximately 99 and 42 days, respectively; this would favour their survival in the nests for long periods. The stable occupation of thornbird nests (both by resident thornbirds and inquilines) probably provides a year-round blood supply for the bugs. This may even apply for nests that are not occupied by breeding birds, because $P$. tertius can also feed on invertebrate hemolymph (NOIREAU et al. 2005), which are common in the nests of thornbirds (Silva \& Lustosa 1993, Gurgel-Gonçalves et al. 2006, Di Iorio \& Turienzo 2009). Thus, continuous food availability would favor the permanence of $P$. tertius in thornbird nests across the Brazilian Cerrado and Caatinga ecoregions.

Table I. Entomological indices of P. tertius in thornbird nests in Brazilian Cerrado and Caatinga ecoregions.

\begin{tabular}{lcccccc}
\hline \multicolumn{1}{c}{ Species } & Ecoregion & $\begin{array}{c}\text { Nests } \\
\text { surveyed }\end{array}$ & $\begin{array}{c}\text { Infested nests } \\
(\%)\end{array}$ & $\begin{array}{c}\text { Bugs } \\
\text { captured }\end{array}$ & $\begin{array}{c}\text { Nymphal instars } \\
(\%)\end{array}$ & $\begin{array}{c}\text { Bugs/infested nest } \\
\text { (range) }\end{array}$ \\
\hline P. ruber & Cerrado & 36 & $26(72)$ & 484 & 60 & $19(1-59)$ \\
P. rufifrons rufifrons & Cerrado & 321 & $136(42)$ & 2024 & 50 & $15(1-75)$ \\
P. rufifrons specularis & Caatinga & 170 & $70(40)$ & 753 & 51 & $11(1-35)$ \\
\hline
\end{tabular}




\section{ACKNOWLEDGEMENTS}

We thank Fábio Oliveira Alves for great fieldwork assistance and Patrícia Gurgel for reviewing the English version. We also thank Dra. Maria E. Bar (Universidad Nacional del Nordeste, Argentina), Dr. Osvaldo Di Iorio (Universidad de Buenos Aires, Argentina) and Dr. Fernando Abad-Franch (Instituto Leônidas e Maria Deane - Fiocruz Amazônia) for providing insightful comments on the manuscript.

\section{LITERATURE CITED}

Abad-Franch, F.; F.A. Monteiro; N.O. Jaramillo; R. Gurgel-GonÇalves; F.B.S. Dias \& L. Diotaiuti. 2009. Ecology, evolution and the long-term surveillance of vector-borne Chagas disease: A multi-scale appraisal of the tribe Rhodniini (Triatominae). Acta Tropica 112: 159-177.

Bar, M.E.; E.B. Oscherov; M.P. Damborsky; M.E. Varela; G. Mizdraji \& E. Porcel. 1992. Triatomismo del Departamento San Luis del Palmar de la Provincia de Corrientes, Argentina. Medicina (Buenos Aires) 52: 193-201.

Bar, M.E.; E.B. Oscherov \& M.P. Damborsky. 1993. Presencia de Triatoma sordida Stål, 1859 en ecótopos urbanos de la ciudad de Corrientes, Argentina. Revista de Saúde Pública 27: 11722.

Bar, M.E.; M.P. Damborsky; B.M. Alvarez; E.B. Oscherov \& S.M. Mazza. 1999. Triatominos silvestres detectados en nidos de aves de algunos departamentos de la provincia de Corrientes, Argentina. Revista de la Sociedad Entomológica Argentina $58(3 / 4): 43-50$.

Barretto, M.P. \& J.R. Carvalheiro. 1968. Estudos sobre reservatórios do Trypanosoma cruzi. XXV: Observações sobre a infestação de ninhos de Anumbius annumbi Vieillot, 1817 e de Phacellodomus rufifrons (Wied-Neuwied, 1821) pelo Psammolestes tertius Lent \& Jurberg, 1965 (Hemiptera, Reduviidae). Revista Brasileira de Biologia 28: 11-17.

Cabello, D.R.; E. Lizano \& A. Valderrama. 1987. Estadísticas vitales de Rhodnius neivai Lent, 1953 (Hemiptera: Reduviidae) en condiciones experimentales. Memórias do Instituto Oswaldo Cruz 82 (4): 511-524.

Carrara, L.A. \& M. Rodrigues. 2001. Breeding biology of the rufousfronted thornbird Phacellodomus rufifrons, a Neotropical ovenbird. International Journal of Ornithology 4 (3/4): 209217.

Di Iorio, O. \& P. Turienzo. 2009. Insects found in birds' nests from the Neotropical Region (except Argentina) and immigrant species of Neotropical origin in the Nearctic Region. Zootaxa 2187: 1-144.

Diotaiuti, L.; C.F. Loiola; P.L. FalCÃo \& J.C.P. Dias. 1993. The ecology of Triatoma sordida in natural environments in two different regions of the State of Minas Gerais, Brazil. Revista do Instituto de Medicina Tropical de São Paulo 35: 237-245.
Gurgel-Gonçalves, R. \& C.A.C. Cuba. 2007. Estrutura de populações de Rhodnius neglectus (Lent) e Psammolestes tertius (Lent \& Jurberg) (Hemiptera, Reduviidae) em ninhos de pássaros (Furnariidae) presentes na palmeira Mauritia flexuosa no Distrito Federal, Brasil. Revista Brasileira de Zoologia 24: 157-163.

GuRgel-GonÇALVES, R. \& R.B. SiLVA. 2009. Analysis of the geographical distribution of Psammolestes Bergroth (Heteroptera: Reduviidae) in South America with new records of Psammolestes tertius Lent \& Jurberg. Zootaxa 2033: 41-48.

Gurgel-Gonçalves, R.; A.R.T. Palma; M.N.A. Menezes; R.N. Leite \& C.A.C. Cuba. 2003. Sampling Rhodnius neglectus (Triatominae) in Mauritia flexuosa palm trees (Arecaceae): a field study in the Brazilian Savanna. Medical and Veterinary Entomology 17: 347-349.

Gurgel-Gonçalves, R.; M.A. Duarte; E.D Ramalho; C.A. Romaña \& C.A.C. Cuba. 2004. Distribuição espacial de populações de Triatominae (Hemiptera, Reduviidae) em palmeiras da espécie Mauritia flexuosa no Distrito Federal, Brasil. Revista da Sociedade Brasileira de Medicina Tropical 37: 241-247.

Gurgel-Gonçalves, R.; A.R.T. Palma; P.C. Motta; M.E. Bar \& C.A.C. CuBA. 2006. Arthropods associated with the Crown of Mauritia flexuosa (Arecaceae) palm trees in three different environments from Brazilian Cerrado. Neotropical Entomology 35 (3): 302-312.

Lent, H. \& J. Jurberg. 1965. O gênero Psammolestes Bergroth, 1911, com um estudo sobre a genitália das espécies. Revista Brasileira de Biologia 25: 349-376.

LuCENA, D.T \& N.T. LuCENA. 1965. Psammolestes coreodes Bergroth, 1911 (Hemiptera, Reduviidae) em Pernambuco, Brasil. Revista do Instituto de Medicina Tropical de São Paulo 7: 160-8.

Mello, D.A. 1981. Aspectos do ciclo silvestre do Trypanosoma cruzi em regiões de Cerrado (município de Formosa, Estado de Goiás). Memórias do Instituto Oswaldo Cruz 76 (3): 227 246.

Mello, D.A. 1982. Roedores, marsupiais e triatomíneos silvestres capturados no Municipio de Mambaí-Goiás. Infecção natural pelo Trypanosoma cruzi. Revista da Saúde pública 16: 282-291.

Noireau, F.; A.L. Carbajal de la fuente; C.M. Lopes \& L. Diotaiuti. 2005. Some considerations about ecology of Triatominae. Anais da Academia Brasileira de Ciências 77 (3): 431-463.

Oscherov, E.B.; M.P. Damborsky; M.E. Bar \& E. Porcel. 1996. Estadísticos poblacionales de Triatoma sordida Stål 1859 (Hemiptera: Reduviidae) en condiciones experimentales. Revista de Saúde Pública 30 (5): 438-43.

Oscherov, E.B.; M.E. Bar; M.P. Damborsky \& A.M.F. Milano. 2005. Estadísticos poblacionales de Triatoma rubrovaria en condiciones de laboratorio. Revista de Saúde Pública 39 (2): 211216.

RabinOVICH, J.E. 1972. Vital statistics of Triatominae (Hemiptera: Reduviidae) under laboratory conditions. I. Triatoma infestans Klug. Journal of Medical Entomology 9: 351-370. 
Sherlock, I.A. \& N. Guitton. 1974. Fauna Triatominae do estado da Bahia, Brasil. II notas sobre ecótopos silvestres e o gênero Psammolestes. Memórias do Instituto Oswaldo Cruz 72: 91-101.

SiLva. I.G. \& E.S. Lustosa. 1993. Biologia de Psammolestes tertius Lent \& Jurgberg, 1965 (Hemiptera, Reduviidae). Revista de Patologia Tropical 22: 29-42.

SkUTCH, A.F. 1969. A study of the Rufous-fronted Thornbird and associated birds, part II: birds which breed in thornbirds' nests. Wilson Bulletin 81: 123-139.

Turienzo, P. \& O. Di Iorio. 2008. Insects found in birds' nests from Argentina: Anumbius annumbi (Vieillot, 1817) (Aves: Furnariidae) Zootaxa 1871: 1-55.

WWF. 2001. Ecoregions. Avaliable online at: http:// www.worldwildlife.org/wildworld/profiles/terrestrial_nt. html. [Accessed: 10/II/2011].

Submitted: 25.I.2011; Accepted: 21.V.2011.

Editorial responsibility: Marcus V. Domingues 